\title{
Flow Cytometric Aldehyde Dehydrogenase Assay Enables a Fast and Accurate Human Umbilical Cord Blood Hematopoietic Stem Cell Assessment
}

\author{
Insan Göbek Kordon Kanı Hematopoetik Kök Hücre Değerlendirmesinde Hızlı ve Etkin Bir \\ Değerlendirme Yöntemi: Akım Sitometrik Aldehit Dehidrogenaz Testi
}

\author{
Emine Begüm Gençer ${ }^{1,2}$, Pınar Yurdakul ${ }^{1,3}$, Klara Dalva, Meral Beksaç \\ ${ }^{1}$ Ankara University Faculty of Medicine, Cord Blood Bank, Ankara, Turkey \\ ${ }^{2}$ Ankara University Faculty of Medicine, Biotechnology Institute, Ankara, Turkey \\ ${ }^{3}$ TOBB Economics Technology and University Faculty of Medicine, Department of Medical Microbiology, Ankara, Turkey \\ ${ }^{4}$ Ankara University Faculty of Medicine, Stem Cell Research Institute, Ankara, Turkey \\ ${ }^{5}$ Ankara University Faculty of Medicine, Department of Hematology, Ankara, Turkey
}

\section{Abstract}

Objective: Colony-forming units of granulocytes/macrophages (CFU-GM) analysis is the most widely used method to determine the hematopoietic stem cell (HSC) content of human umbilical cord blood (CB) for prediction of engraftment potential. The measurement of aldehyde dehydrogenase (ALDH) activity is a more recent method for HSC qualification. Our aim was to correlate phenotypic and functional assays to find the most predictive method.

Materials and Methods: In this study, flow cytometric quantitation of $\mathrm{CD} 34^{+}$cells and ALDH positivity along with CFU-GM capacity were assessed in fresh and post-thaw CB units.

Results: Among 30 post-processing samples, for each $\mathrm{CB}$ unit the mean total number of nucleated cells (TNCs) was $(93.8 \pm 30.1) \times 10^{7}$, $\mathrm{CD} 4^{+}$cells were $(3.85 \pm 2.55) \times 10^{6}, \mathrm{ALDH}^{+}$cells were $(3.14 \pm 2.55) \times 10^{6}$, and CFU-GM count was $(2.64 \pm 1.96) \times 10^{5}$. Among an additional 19 postthaw samples the cell counts were as follows: TNCs, $(32.79 \pm 17.27) \times 10^{7}$; $\mathrm{CD}^{+} 4^{+},(2.18 \pm 3.17) \times 10^{6} ; \mathrm{ALDH}^{+},(2.01 \pm 2.81) \times 10^{6} ; \mathrm{CFU}-\mathrm{GM},(0.74 \pm 0.92)$ $\mathrm{x} 10^{5}$. Our findings showed that in fresh samples TNCs, CD34+ cells, and ALDH correlated highly with counts of CFU-GM, CFU-erythroids/ granulocytes-macrophages/megakaryocytic cells (GEMM), and burst forming units of erythroids (BFU-E) as follows: TNCs, $r=0.47, r=0.35$, $r=0.41 ; C^{2} 34^{+}, r=0.44, r=0.54, r=0.41 ;$ and ALDH, $r=0.63, r=0.45$, $r=0.6$, respectively. In terms of post-thaw samples, the correlations were as follows: TNCs, $r=0.59, r=0.46, r=0.56 ; C^{2} D 34^{+}, r=0.67, r=0.48$, $r=0.61$; and ALDH, $r=0.61, r=0.67, r=0.67$, for CFU-GM, CFU-GEMM, and $B F U-E_{1}$ respectively. All correlations were statistically significant.

\section{Öz}

Amaç: Granülositer makrofaj koloni oluşturma (CFU-GM) testi kordon kanı (KK) hematopoietik kök hücre engrafman potensiyelini ölçmek için kullanılan bir yöntemdir. Aldehit dehidrogenaz (ALDH) enzimi ölçüm yöntemide hematopoetik kök hücre $(\mathrm{HKH})$ kalitesini belirlemek amacıyla kullanılan daha yeni bir metottur. Çalışmamızda fenotipik ve fonksiyonel olarak korelasyon analizi yapılarak HKH ölçümünde en etkili metodu bulmayı amaçladık.

Gereç ve Yöntemler: Bu çalışmada taze ve donma çözme sonrası $\mathrm{KK}$ ünitelerinde $\mathrm{CD}^{+} 4^{+}$ve $\mathrm{ALDH}^{+}$hücrelerle $\mathrm{CFU}-\mathrm{GM}$ kapasiteleri araştırılmıştır.

Bulgular: Otuz taze KK ünitesinde her KK için ortalama değerler: Toplam çekirdekli hücre sayısı (TNC): $93,8 \pm 30,1 \times 10^{7}$, CD34+: $3,85 \pm 2,55 \times 10^{6}, \mathrm{ALDH}^{+}: 3,14 \pm 2,55 \times 10^{6}, \mathrm{CFU}-\mathrm{GM}: 2,64 \pm 1,96 \times 10^{5}$. On dokuz KK ünitesinde donma çözme sonrası hücre değerleri: TNC: $32,79 \pm 17,27 \times 10^{7}, \mathrm{CD} 34^{+}: 2,18 \pm 3,17 \times 10^{6}, \mathrm{ALDH}^{+}: 2,01 \pm 2,81 \times 10^{6}, \mathrm{CFU}-$ GM: $0,74 \pm 0,92 \times 10^{5}$ dir. Bulgularımız; taze KK'da TNC, CD34 ve ALDH; CFU-GM, CFU-GEMM ve BFU-E ile korelasyon gösterirken (TNC, $r=0,47$, $r=0,35, r=0,41$; CD34 ${ }^{+}, r=0,44, r=0,54 r=0,41$; ve ALDH, $r=0,63 r=0,45$ $r=0,6)$ donma çözme sonrası KK'da korelasyon sırasıyla CFU-GM, CFU-GEMM, ve BFU-E için, TNC $r=0,59, r=0,46, r=0,56, C D 34^{+} r=0,67$, $r=0,48, r=0,61$ ve ALDH $r=0,61, r=0,67, r=0,67$ olarak saptanmıştır. Bütün bulgularımız istatistiksel olarak anlamlı çıkmıştır.

Sonuç: Çalışmamız, ALDH aktivitesi tayin metodu HKH tayininde geleneksel yöntemlerle özellikle donma çözme sonrası örnekler açısından korelasyon göstermiştir. Böylelikle hızlı, ucuz bir metod 
Conclusion: In our experience, HSC assessment by ALDH activity yields the highest correlation with conventional analytical methods, particularly for post-thaw samples. Thus, this fast, inexpensive method has the potential to overcome the weaknesses of other techniques.

Keywords: Cord blood, Aldehyde dehydrogenase, Colony-forming unit-granulocyte/macrophage olarak ALDH diğer HKH belirlemede kullanılan yöntemlere üstün olabilecek kapasitededir.

Anahtar Sözcükler: Göbek kordon kanı, Aldehit dehidrogenaz, Koloni oluşturan birim granülositer/makrofaj

\section{Introduction}

Recent scientific evidence demonstrates that different subtypes of $\mathrm{CD}_{3} 4^{+}$cells in the cord blood (CB) hematopoietic stem cell (HSC) niche have different engraftment potentials $[1,2]$. It is of crucial importance to determine the quality of the CB particularly following freeze/thaw cycles. Two different approaches can be used to assess the functionality and population-forming capacities of CB HSCs along with the gold standard method of the International Society of Hematotherapy and Graft Engineering (ISHAGE) [3]. Ex vivo colony-forming unit (CFU) assays are the most widely used tests for determining HSC functions, but they possess serious drawbacks such as difficulty in routine application, lack of standardization, labor-intensive nature, and long turnaround time [4]. One of the likely reasons for this is probably the fact that while being predictive of shortterm re-populating cells, CFU assays could not determine longterm populating cells effectively. Long-term populating cells have been shown to provide long-term immune reconstitution after CB transplantation (CBT); thus, it is of crucial importance to assess their numbers. The measurement of aldehyde dehydrogenase (ALDH) activity can therefore be much more accurate due to the intracellular presence of this enzyme [5].

It was reported that ALDH enzyme expression is high in early HSCs in the bone marrow and $C B[6,7]$. A few published studied correlated high ALDH activity with better permanent engraftment following HSC transplantation $[5,7,8,9,10,11]$. In the first such study by Lioznov et al. [12], it was reported that ALDH expression is a practical marker to assess HSC activity for both stem and progenitor cells before bone marrow and peripheral blood transplantation. There are hardly any data for $\mathrm{CB}$ investigating the phenotypic and functional properties of $\mathrm{CB}$ HSCs and the correlation of ALDH activity with CFU potential in pre- and post-thaw CB HSCs $[5,7,11,13,14]$. In this study, we aimed to correlate phenotypic assays with functional assays to find the most predictive method for fresh and post-thaw CB.

\section{Materials and Methods}

\section{CB Unit Selection and Processing}

A total of $50 \mathrm{CB}$ units from consenting maternal donors collected at the Ankara University Faculty of Medicine's Cord Blood Bank were included in this study. Thirty CB units that met volume and total number of nucleated cell (TNC) eligibility criteria ( $>70 \mathrm{~mL}$ and
$100 \times 10^{7} / U$, respectively) were processed and used immediately for the fresh group and 20 non-conforming CB units that had been reserved for research purposes were included as the post-thaw group (1 unit was discarded due to CFU culture contamination). CB units were processed automatically with a Sepax 2 device (Biosafe) and TNC counts, post-processing CD $34^{+}$cell enumeration, and cell viabilities were assessed for every $\mathrm{CB}$ unit.

\section{Post-Thaw Washing}

Nineteen non-conforming $\mathrm{CB}$ units were thawed in a $37^{\circ} \mathrm{C}$ water bath and samples of $10 \mathrm{~mL}$ were taken into conical tubes. In order to remove DMSO, CB units were washed using a washing solution (10\% dextran 40 (BioFleks), 20\% human serum albumin (Centurion Pharma), and PBS (Lonza) at 4:1:3/8 (v/v), respectively). Upon thawing of the $\mathrm{CB}$ units they were washed twice with 1:1 (v/v) washing solution After discarding the supernatant, the pellet was re-suspended in washing solution by gentle mixing.

\section{Determination of TNC/CD34 Viability and Counts}

The number of TNCs for all units (30 fresh and 19 post-thaw units) was assessed by complete blood counting with an automated cell counter (Beckman Coulter, LH780). CB unit $\mathrm{CD}_{3}{ }^{+}$cell enumeration and detection of cell viability by 7-aminoactinomycin dye was performed using a Stem-Kit upon the acquisition of the data with an FC 500 instrument (Beckman Coulter). The analysis was performed using an ISHAGE single test platform.

\section{ALDH Analysis}

The ALDEFLUOR assay (StemCell Technologies) was used for the detection of ALDH expression in fresh and post-thaw CB HSCs. ALDH activity was measured by the protocol recommended by the manufacturer. Briefly, cell suspensions were adjusted to $10^{6}$ cells $/ \mathrm{mL}$ with $1500 \mu \mathrm{L}$ of ALDEFLUOR assay buffer after red blood cell depletion. ALDEFLUOR reagent $(10 \mu \mathrm{L})$ was added to each tube, followed by $5 \mathrm{~min}$ of centrifugation at $300 \times \mathrm{g}$. Supernatants were stained with FITC-ALDH, APC A-750-CD38, phycocyanin (PC) 7-CD34, chrome orange-CD45 (Beckman Coulter), PE-CD73, and PC 5-CD90 (Becton Dickinson) antibodies and analyzed by flow cytometry (Beckman Coulter FC500). Diethylaminobenzaldehyde reagent was used to suppress ALDH activity in control tubes. Using the ALDH activity assay, CB HSCs were categorized as $\mathrm{ALDH}^{+}$and $\mathrm{ALDH}$. 


\section{CFU Assays}

CFU assays were implemented according to the manufacturer's recommendations (StemCell Technologies CFU Manual, MA28404) and modified from Lee et al. [19]. First, $100 \mu \mathrm{L}$ of $\mathrm{CB}$ sample was removed from all $\mathrm{CB}$ units, and after the addition of $80 \mu \mathrm{L}$ of HetaSep and $300 \mu \mathrm{L}$ of Iscove's modified Dulbecco medium containing 2\% fetal bovine serum (StemCell Technologies), the mixture was incubated at $37{ }^{\circ} \mathrm{C}$ in $5 \% \mathrm{CO}_{2}$ for $20 \mathrm{~min}$ (Sanyo $\mathrm{CO}_{2}$ Incubator). Cells $\left(5 \times 10^{5} \mathrm{cells} / \mathrm{mL}\right)$ were transferred to $3 \mathrm{~mL}$ of MethoCult Express medium. After 14 days, colonies were counted and different morphologies as well as numbers of CFUs were recorded using an inverted light microscope (Olympus/IX51). The number of colonies was calculated as the mean value for two dishes.

\section{Statistical Analysis}

Pearson correlation coefficient tests (if data distribution was normal) and Spearman rank correlation coefficient tests (if data distribution was not in the normal range) were used to assess the correlations. All statistical analyses were performed with SPSS 15.0.

\section{Results}

In this study we aimed to compare three different methods in terms of efficiency to assess different re-populating HSCs from $\mathrm{CB}$, both after processing and after thawing. We analyzed different cellular fractions, namely $\mathrm{TNCs} ; \mathrm{CD} 34^{+}, \mathrm{ALDH}^{+}, \mathrm{CD} 34^{+}$ $\mathrm{ALDH}^{+}, \mathrm{ALDH}^{+} \mathrm{CD}_{4} 4^{+}$, and $\mathrm{ALDH}^{+} \mathrm{CD} 34^{+} \mathrm{CD}^{-} 0^{+} \mathrm{CD} 38^{-}$cells; and colony-forming units of granulocytes/macrophages (CFU-GM), CFU-erythroids/granulocytes-macrophages/megakaryocytic cells (GEMM), and burst forming units of erythroids (BFU-E), for both fresh and post-thawed units. Table 1 demonstrates the mean, median, and minimum-maximum values of the aforementioned parameters for fresh and post-thawed samples.

Table 2 provides the correlation values for ALDH positivity and

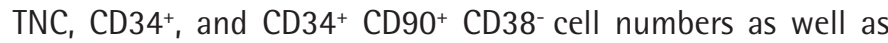
CFU-GM, CFU-GEMM, and BFU-E colony counts among all CB samples. When fresh samples were analyzed, ALDH activity correlated well with all the cell populations investigated; TNC, $\mathrm{ALDH}^{+}$, and $\mathrm{CD} 34^{+}$fractions were found to be highly correlated both with CFU-GM, CFU-GEMM, and BFU-E and with each other. The correlation coefficients remained significant for fresh and post-thawed samples, and when post-thaw data were analyzed, TNCs, CD34+, and ALDH were also found to be statistically correlated with CFU-GM, CFU-GEMM, and BFU-E (Table 2).

Among all parameters compared, the most striking correlation was detected for CFU-GM numbers and ALDH positivity for fresh $C B$ units $(r=0.629, p<0.001)$; post-thaw analyses also revealed a correlation for $\mathrm{CFU}-\mathrm{GM}$ and $\mathrm{ALDH}^{+}$cells when the same parameters were investigated $(r=0.608, p=0.006$; Table 2$)$. When CFU-GM numbers were tested against all parameters for

\begin{tabular}{|c|c|c|c|c|}
\hline \multicolumn{2}{|c|}{ Variables (fresh CB units, $n=30$; post-thaw CB units, $n=19$ ) } & \multirow{2}{*}{$\begin{array}{l}\text { Mean } \pm \text { SD } \\
93.8 \pm 30.1\end{array}$} & \multirow{2}{*}{\begin{tabular}{|l} 
Median \\
85.5 \\
\end{tabular}} & \multirow{2}{*}{$\begin{array}{l}\text { Minimum - maximum } \\
46.8-168.8\end{array}$} \\
\hline TNC & Fresh & & & \\
\hline$\left(x 10^{7} / U\right)$ & Post-thaw & $32.79 \pm 17.27$ & 31.05 & $9.2-47.6$ \\
\hline \multirow{2}{*}{$\begin{array}{l}\text { CD34+ } \\
\left(\times 10^{6} / U\right)\end{array}$} & Fresh & $3.85 \pm 2.55$ & 3.6 & $0.94-11.64$ \\
\hline & Post-thaw & $2.18 \pm 3.17$ & 1.18 & $0.5-14.5$ \\
\hline \multirow{2}{*}{$\begin{array}{l}\mathrm{ALDH}^{+} \\
\left(\times 10^{6} / \mathrm{U}\right)\end{array}$} & Fresh & $3.14 \pm 2.55$ & 2.6 & $0.12-8.48$ \\
\hline & Post-thaw & $2.01 \pm 2.81$ & 1.38 & $0.20-11.3$ \\
\hline \multirow{2}{*}{$\begin{array}{l}\mathrm{ALDH}^{+} / \mathrm{CD} 4^{+} \\
\left(\times 10^{6} / \mathrm{U}\right)\end{array}$} & Fresh & $2.97 \pm 2.02$ & 2.4 & $0.11-8.12$ \\
\hline & Post-thaw & $1.82 \pm 2.63$ & 1.28 & 0.17-1.69 \\
\hline \multirow{2}{*}{$\begin{array}{l}\mathrm{CD} 34^{+} / \mathrm{ALDH}^{+} \\
\left(\mathrm{x} 10^{6} / \mathrm{U}\right)\end{array}$} & Fresh & $3.72 \pm 2.28$ & 2.9 & $0.34-8.94$ \\
\hline & Post-thaw & $3.01 \pm 4.33$ & 1.65 & $0.29-15.31$ \\
\hline \multirow{2}{*}{$\begin{array}{l}\mathrm{ALDH}^{+} / \mathrm{CD} 0^{+} / \mathrm{CD}^{2} 4^{+} / \mathrm{CD} 38- \\
\left(\times 10^{6} / \mathrm{U}\right)\end{array}$} & Fresh & $0.19 \pm 0.19$ & 0.1 & $0.005-0.795$ \\
\hline & Post-thaw & $0.40 \pm 0.55$ & 0.2 & $0.01-1.92$ \\
\hline \multirow{2}{*}{$\begin{array}{l}\text { CFU-GM } \\
\left(\times 10^{5} / \mathrm{U}\right)\end{array}$} & Fresh & $2.64 \pm 1.96$ & 2.14 & $0.25-7.67$ \\
\hline & Post-thaw & $0.74 \pm 0.92$ & 0.41 & $0.02-2.92$ \\
\hline \multirow{2}{*}{$\begin{array}{l}\text { CFU-GEMM } \\
\left(\times 10^{5} / \mathrm{U}\right)\end{array}$} & Fresh & $3.86 \pm 2.73$ & 3.6 & 0.66-11.49 \\
\hline & Post-thaw & $0.70 \pm 0.98$ & 0.36 & $0-4.27$ \\
\hline \multirow{2}{*}{$\begin{array}{l}\text { BFU-E } \\
\left(\times 10^{5} / U\right)\end{array}$} & Fresh & $5.30 \pm 3.53$ & 5.6 & $0.12-16.22$ \\
\hline & Post-thaw & $0.44 \pm 0.74$ & 0.19 & $0-2.9$ \\
\hline
\end{tabular}









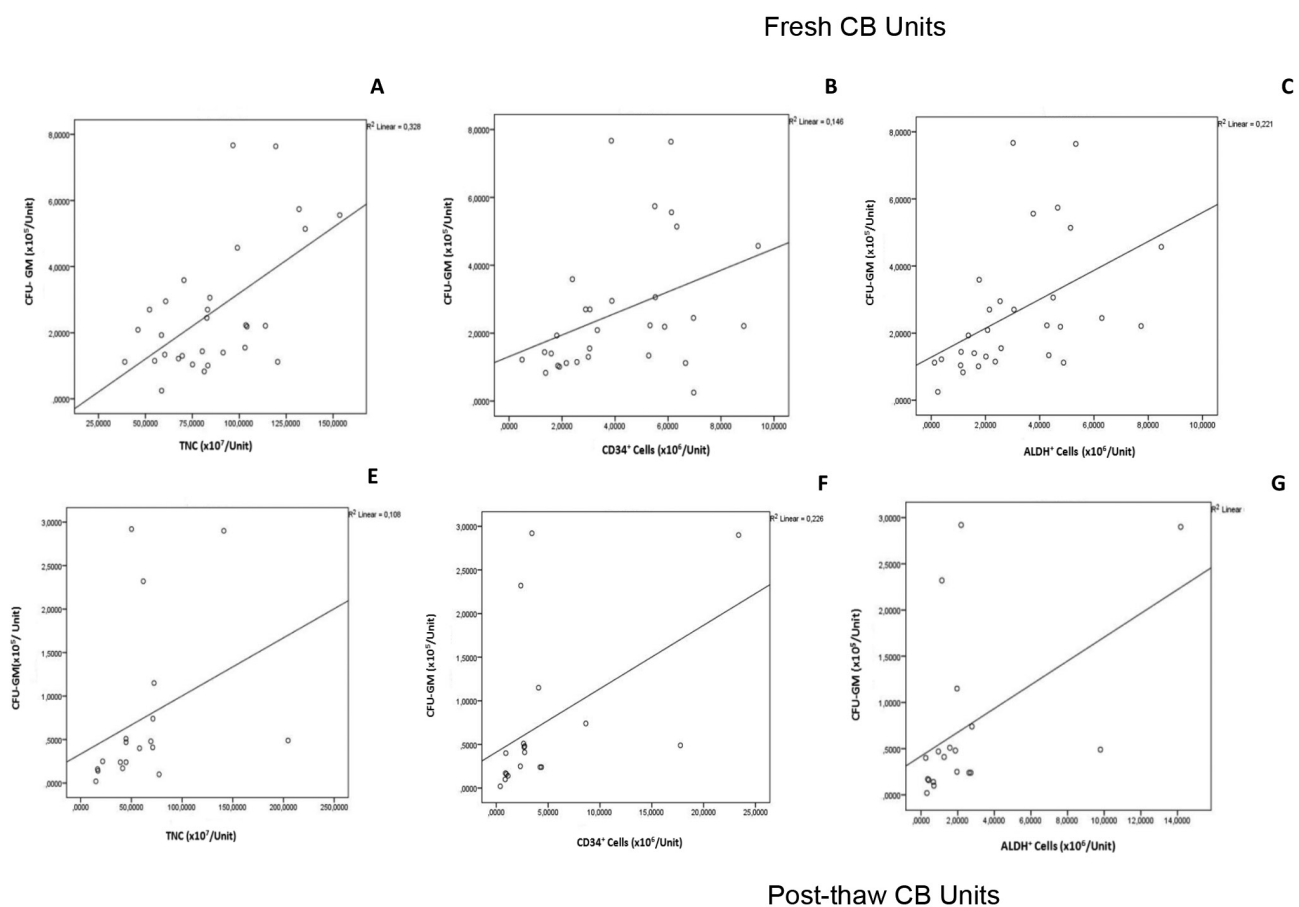

c

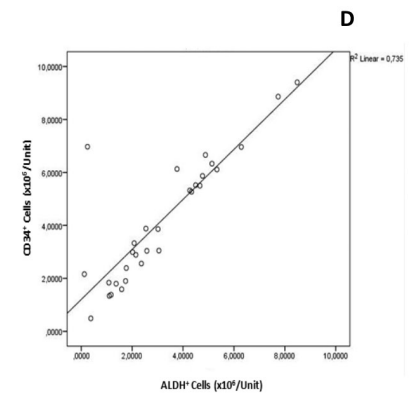

G

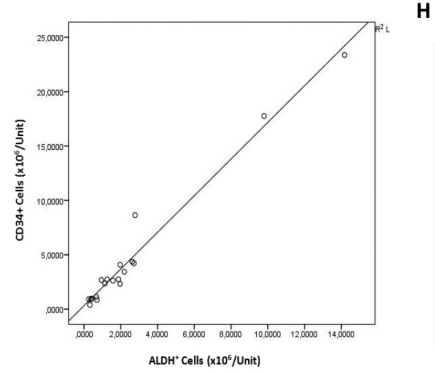

Figure 1. Correlation values of TNCs, ALDH, and CD34 cells with CFU-GM and ALDH+ CD34+ cells. Graphs A-D denote correlations for fresh CB units: TNCs and CFU-GM (A); CD34 ${ }^{+}$cells and CFU-GM (B); ALDH ${ }^{+}$cells and CFU-GM (C); CD34 $4^{+}$cells and ALDH ${ }^{+}$cells (D). Graphs E-H denote correlations for post-thaw samples: TNCs and CFU-GM (E); CD34+ and CFU-GM (F); $\mathrm{ALDH}^{+}$and CFU-GM (G); CD34+ cells and $\mathrm{ALDH}^{+}$cells $(\mathrm{H})$.

CB: Cord blood, TNC: total number of nucleated cells, ALDH: aldehyde dehydrogenase, CFU-GM: colony-forming units granulocytes/macrophages.

post-thawed samples, an even higher correlation was detected in $\mathrm{CD}_{3} 4^{+}$cells, which were also positive for ALDH ( $r=0.670$, $\mathrm{p}=0.002)$. On the other hand, there was no significant correlation between TNCs and $\mathrm{ALDH}^{+}$cells, which were also positive for CD34 $(r=0.432, p=0.065)$. These correlations are shown in Figure 1. Table 2 shows $r$ values for all parameters investigated.

\section{Discussion}

One of the recent methods described for the rapid and accurate detection of functional CB cell fractions is ALDH activity measurement in CB HSCs. To date, five studies have looked at ALDH levels in CB units $[5,7,11,13,14]$. Our study is unique in terms of having a detailed post-thaw analysis and to our knowledge it is also the first to determine the capacity of $\mathrm{ALDH}^{+} \mathrm{CD} 0^{+} \mathrm{CD}^{+} 4^{+} \mathrm{CD} 38^{-}$cells, a group of cells that possess high engraftment capacity. Most of the papers in the literature have focused on HSCs with high ALDH activity with conflicting results related to their role in engraftment following HSC transplantation $[11,14,15,16]$. An experiment carried out by Pearce et al. [17] showed that ALDH and CD34 double-positive cells constitute $63 \%$ of lineage-negative cells for TNCs and only $\mathrm{ALDH}^{+}$cells improved engraftment. Storms et al. [18] classified $\mathrm{HSCs}$ as being $\mathrm{CD}_{3} 4^{+-}, \mathrm{ALDH}^{+}$, and $\mathrm{ALDH}^{-}$and demonstrated that only $\mathrm{CD}_{3} 4^{+} \mathrm{ALDH}^{+}$cells were efficient in terms of longterm and short-term re-population capacities.
Shoulars et al. [11] developed an ALDH-based method to estimate the post-thaw quality of $\mathrm{CB}$ units. The results of their study, similar to ours, demonstrated that ALDH activity is highly correlated with CFU counts and can be integrated into routine CB unit release procedures prior to transplantation. Thus, our findings, which show the highest correlation between in vitro CFU counts and ALDH activity compared to TNCs or CD34, are confirmed by this very recent publication.

We aimed to compare three different approaches to assess different re-populating $\mathrm{HSCs}$ from $\mathrm{CB}$, both fresh and after thawing. In our study, CD34 ${ }^{+}$cells were found to constitute $0.49 \pm 0.26 \%$ of all TNCs and $0.35 \pm 0.21 \%$ of $\mathrm{ALDH}^{+}$cells. Additionally, $86.98 \pm 13 \%$ of all $\mathrm{CD} 34^{+}$cells were found to be $\mathrm{ALDH}^{+}$, and within all $\mathrm{ALDH}^{+}$cells, 94.54 $\pm 5.3 \%$ were $\mathrm{CD}^{+} 4^{+}$. Among all $\mathrm{CB}$ units tested, the rate of $\mathrm{ALDH}^{+} \mathrm{CD} 34^{-}$cells was found to be $5.46 \%$ and $13.02 \%$ were $\mathrm{ALDH}^{-}$but CD34+. Different research groups sought to identify different cellular populations by ALDH staining intensities, but only two of them compared the ALDH activity of different CB sub-populations $[5,19]$. The clinical significance of those populations remains to be determined. In a study by Lee et al., [7] CD34 cells were found to constitute $0.14 \pm 0.10 \%$ of all TNCs. In comparison, CD34 positivity was seen in $0.49 \pm 0.26 \%$ of all TNCs in our study. Unlike our results, Lee et al. [7] detected less ALDH positivity among $\mathrm{CD}^{+} 4^{+}$cells $(74.5 \pm 13.8 \%)$, and of the entire $\mathrm{ALDH}^{+}$ 
population, $69.9 \pm 15.5 \%$ of cells were shown to express CD34. Another similar investigation by Storms et al. [18] demonstrated even higher HSC rates in fresh CB samples: $0.9 \pm 0.5 \%$ of TNCs were $\mathrm{CD} 34^{+}$, but $47.9 \pm 14.3 \%$ of those cells were $\mathrm{ALDH}^{+}$. $\mathrm{ALDH}^{+}$ cells constituted $0.96 \pm 0.5 \%$ of TNCs and $50.9 \pm 18.3 \%$ of $\mathrm{ALDH}^{+}$ cells were CD34+ [18]. In Gentry et al's [10] study CD34+ cell count was found to be $0.15 \pm 0.08 \%$ of all TNCs, and $0.05 \pm 0.02 \%$ of TNCs expressed high ALDH.

Attia et al. [14] reported that ALDH activity detection is not only quick and easy to perform but also it does not affect the cell viability or re-populating capacity of $\mathrm{CB}$ cells, which may be a serious drawback of some CD34 detection systems [20]. Ikeda et al. [13] suggested that prior to CBT the ALDH assessment method could be an alternative approach to the selection of CB units for unrelated donors [14]. All of the results from the papers mentioned here are in favor of our findings indicating the utility of an ALDH-based approach for CBT settings.

Characterization of the sub-populations of CB is crucial because high cell doses with adequate viability predict the outcome after CBT. Engraftment is generally ensured when highly CD34+ cells are used, but occasionally a graft with partially dysfunctional cells due to freeze/thaw processes can affect the cells' shortterm and long-term re-populating capacities [20]. In vitro manipulations have been shown to interfere with membrane CD34 expression without hampering HSC functionality $[21,22]$. With the ALDH analysis approach, HSCs with relatively high engraftment capacity but with limited or no growth in CFU tests can easily be detected.

As we sought to determine the correlation levels for TNCs and $\mathrm{ALDH}^{+}$and $\mathrm{CD} 34^{+}$cells with CFU capacities for both fresh and post-thaw samples, we demonstrated that ALDH positivity correlated highly with CFU-GM capacity $(r=0.629, p<0.001)$ in fresh samples. On the other hand, the highest correlation was detected for CFU-GM numbers and CD34+ cells for the post-thaw group of CB units $(r=0.655, p<0.001)$ (Table 2). With a similar approach, Lee et al. [19] analyzed $\mathrm{ALDH}^{+}, \mathrm{CD}^{4} 4^{+}, \mathrm{ALDH}^{+}$within $\mathrm{CD}_{4} 4^{+}$, and $\mathrm{CD} 34^{+}$within $\mathrm{ALDH}^{+}$cell populations and CFU-GM and CFU-GEMM capacities in 245 CB units, both fresh and after thawing. Unlike our results, CFU-GM count was not found to be correlated with TNCs in their study. In addition to Lee et al's [19] approach, $\mathrm{ALDH}^{+} \mathrm{CD} 90^{+} \mathrm{CD} 34^{+} \mathrm{CD} 38^{-}$cell populations and BFU-E capacities were also analyzed in our study. Lee et al. [19] did not provide any data related to post-thaw samples in terms of TNC/ALDH and TNC/CD34+ ratios, but we demonstrated in our study that $0.66 \pm 0.4 \%$ of TNCs were CD $34^{+}$cells and $0.37 \pm 0.27 \%$ of TNCs were $\mathrm{ALDH}^{+}$cells.

In a phase 1 study by Gentry et al. [10], CD34+ cell counts were claimed to be the sole post-thaw $\mathrm{CB}$ quality predictor, indicating a lower transplant-related mortality, but post-thaw comparisons of CFU-GM counts versus ALDH activity were not conducted. In our study, ALDH+ cells correlated well with CFUGM for post-thaw samples (Table 2). Similar to our results, a positive correlation was detected between $\mathrm{ALDH}^{+}$cells and CFUGM positivity $(r=0.40, p=0.03)$ in Frandberg et al.'s [5] study, but their work did not reveal any correlation of CD34+ cells with total CFU count $(r=0.36, p=0.051)$.

In addition to ALDH positivity, determination of $\mathrm{CD} 90^{+} \mathrm{CD} 34^{+}$ CD38- cells may also be a good predictor of engraftment both for fresh and post-thaw $\mathrm{CB}$ units. The $\mathrm{ALDH}^{+} \mathrm{CD} 90^{+} \mathrm{CD} 34^{+} \mathrm{CD} 38^{-}$ group of progenitors is unique with their high engraftment and re-populating capacities $[23,24,25]$. To our knowledge, our study is the first to examine the ALDH capacity of these particular cells. When we analyzed ALDH positivity in $\mathrm{CD}^{2} 0^{+} \mathrm{CD} 34^{+} \mathrm{CD} 38$ cells, CFU-GM, CFU-GEMM, and BFU-E counts were found to be well correlated for both fresh and post-thaw $\mathrm{CB}$ units (Table 2). Putman et al. [9] performed CFU tests for $A L D H^{\text {hi }}$ and $A L D H^{10}$ cellular populations of CB BFU-E, CFU-GM, and CFU-GEMM. In our study the highest correlation of $\mathrm{ALDH}^{+}$cells was found with CFU-GM and BFU-E for fresh samples. Putman et al. [9] found that the $C B A L D H^{\text {hi }}$ population was significantly enriched for human hematopoietic progenitor function.

Owing to the nature of ALDH as an intracellular enzyme, it may be less affected by centrifuge force and thus may reflect the actual HSC population in a more realistic manner. By using ALDH as a marker of functionality, the disadvantage of a likely false negativity caused by CD34 $4^{+}$cell counting could also be overcome. Similar to our results, Shoulars et al. [11] from Duke University recently demonstrated that ALDH activity measured from post-thaw segments highly correlated with CFUs. They suggested that measurement of $\mathrm{ALDH}^{\text {br }} \mathrm{CD}^{+} 4^{+}$cells might indicate CFU potency and thus engraftment capacity.

\section{Conclusion}

In light of our results and other recently published studies, we propose that ALDH activity determination can substitute for CFU-GM tests. This fast and inexpensive method has the potential to overcome the weaknesses of other techniques, such as the limitations of CD34 counting due to the internalization of membrane CD34 expression or lack of standardization and long turnaround time of CFU assays. We are aware of the limitations in engraftment prediction by phenotype-based analysis. ALDH measurement, as confirmed by us, has the highest correlation with in vitro functional assays. Currently CD34 and CFUGM assays, accepted as golden standards, are expected to be replaced by ALDH measurement, which is a fast, reproducible, and accurate assessment tool.

\section{Acknowledgments}

This study was supported by the Scientific and Technological Research Council of Turkey (TÜBITAK, 114S829). We are grateful to Handan Karakaya for her kind assistance in the $\mathrm{CB}$ 
processing lab and to Sema Meriç for her assistance in flow cytometry analysis. We would like to thank Dr. Sinan Beksaç and Dr. Doruk C. Katlan for their assistance with CB collection. This study was presented as a poster at the $8^{\text {th }}$ National Bone Marrow Transplantation and Stem Cell Therapy Congress as "Phenotypical Analysis of Ex Vivo Granulocyte Colony-Forming Human Umbilical Cord Blood Cells".

\section{Ethics}

\section{Ethics Committee Approval: Ankara University Faculty of Medicine, Clinical Research Ethics Committee (04-173- 13/11.03.2013).}

Informed Consent: This study was based on blood bank data.

\section{Authorship Contributions}

Surgical and Medical Practices: M.B.; Concept: M.B., P.Y.; Design: M.B.; Data Collection or Processing: E.B.G.; Analysis or Interpretation: E.B.G., K.D.; Literature Search: E.B.G., P.Y.; Writing: E.B.G.

Conflict of Interest: The authors of this paper have no conflicts of interest, including specific financial interests, relationships, and/or affiliations relevant to the subject matter or materials included.

\section{References}

1. Wognum B, Yuan N, Lai B, Miller CL. Colony forming cell assays for human hematopoietic progenitor cells. Methods Mol Biol 2013;946:267-283.

2. Migliaccio AR, Adamson JW, Stevens CE, Dobrila NL, Carrier CM, Rubinstein P. Cell dose and speed of engraftment in placental/umbilical cord blood transplantation: graft progenitor cell content is a better predictor than nucleated cell quantity. Blood 2000;96:2717-2722.

3. Leuner $S$, Arland $M$, Kahl $C$, Jentsch-Ullrich K, Franke A, Höffkes HG. Enumeration of CD34-positive hematopoietic progenitor cells by flow cytometry: comparison of a volumetric assay and the ISHAGE gating strategy. Bone Marrow Transplant 1998;22:699-706.

4. Beksac M, Preffer F. Is it time to revisit our current hematopoietic progenitor cell quantification methods in the clinic? Bone Marrow Transplant 2012;47:1391-1396.

5. Frandberg S, Borestrom C, Li S, Fogelstrand L, Palmqvist L. Exploring the heterogeneity of the hematopoietic stem and progenitor cell pool in cord blood: simultaneous staining for side population, aldehyde dehydrogenase activity, and CD34 expression. Transfusion 2015;55:1283-1289.

6. Balber AE. Concise review: aldehyde dehydrogenase bright stem and progenitor cell populations from normal tissues: characteristics, activities, and emerging uses in regenerative medicine. Stem Cells 2011;29:570-575.

7. Lee HR, Shin S, Yoon JH, Roh EY, Kim BJ, Song EY. Aldehyde dehydrogenasebright cells correlated with the colony-forming unit-granulocytemacrophage assay of thawed cord blood units. Transfusion 2014;54:18711875.

8. Christ O, Lucke K, Imren S, Leung K, Hamilton M, Eaves A, Smith C, Eaves C. Improved purification of hematopoietic stem cells based on their elevated aldehyde dehydrogenase activity. Haematologica 2007;92:1165-1172.
9. Putman DM, Liu KY, Broughton HC, Bell Gl, Hess DA. Umbilical cord bloodderived aldehyde dehydrogenase-expressing progenitor cells promote recovery from acute ischemic injury. Stem Cells 2012;30:2248-2260.

10. Gentry T, Deibert E, Foster SJ, Haley R, Kurtzberg J, Balber AE. Isolation of early hematopoietic cells, including megakaryocyte progenitors, in the ALDH-bright cell population of cryopreserved, banked UC blood. Cytotherapy 2007;9:569-576.

11. Shoulars K, Noldner P, Troy JD, Cheatham L, Parrish A, Page K, Gentry $T$, Balber $A E$, Kurtzberg J. Development and validation of a rapid, aldehyde dehydrogenase bright-based cord blood potency assay. Blood 2016;127:2346-2354.

12. Lioznov MV, Freiberger $P$, Kroger N, Zander AR, Fehse B. Aldehyde dehydrogenase activity as a marker for the quality of hematopoietic stem cell transplants. Bone Marrow Transplant 2005;35:909-914.

13. Ikeda $H$, Toyama $D$, Matsuno R, Fujimoto $Y$, Isoyama K. Aldehyde dehydrogenase activity as a marker of quality in cryopreserved cord blood. Showa University Journal of Medical Sciences 2013;25:297-306.

14. Attia FM, El Baz AA, Naeim MA, Hassan AM, Mohamed AAM, El Barbary MA. Flowcytometric analysis of aldehyde dehydrogenase activity in mononuclear cells from umbilical cord blood. International Journal of Medicine and Medical Sciences 2014;6:151-157.

15. Allan DS, Keeney M, Howson-Jan K, Popma J, Weir K, Bhatia M, Sutherland DR, Chin-Yee IH. Number of viable CD34+ cells reinfused predicts engraftment in autologous hematopoietic stem cell transplantation. Bone Marrow Transplant 2002;29:967-972.

16. Emminger $W$, Emminger-Schmidmeier $W$, Höcker $P$, Hinterberger $W$, Gadner H. Myeloid progenitor cells (CFU-GM) predict engraftment kinetics in autologous transplantation in children. Bone Marrow Transplant 1989;4:415-420.

17. Pearce DJ, Taussig D, Simpson C, Allen K, Rohatiner AZ, Lister TA, Bonnet D. Characterization of cells with a high aldehyde dehydrogenase activity from cord blood and acute myeloid leukemia samples. Stem Cells 2005;23:752760.

18. Storms RW, Green PD, Safford KM, Niedzwiecki D, Cogle CR, Colvin OM, Chao NJ, Rice HE, Smith CA. Distinct hematopoietic progenitor compartments are delineated by the expression of aldehyde dehydrogenase and CD34. Blood 2005; 106:95-102.

19. Lee HR, Song EY, Shin S, Roh EY, Yoon JH, Kim BJ. Quality of cord blood cryopreserved for up to 5 years. Blood Res 2014;49:54-60.

20. Duggleby RC, Querol S, Davy RC, Fry U, Gibson DA, Horton RB, Mahmood SN, Gomez SG, Madrigal JA. Flow cytometry assessment of apoptotic CD34+ cells by annexin $\mathrm{V}$ labeling may improve prediction of cord blood potency for engraftment. Transfusion 2012;52:549-559.

21. Mehrishi JN. Current and historical perspectives on methodological flaws in processing umbilical cord blood. Transfusion 2013;53:2667-2674.

22. Mehrishi JN, Bakacs T. A novel method of CD34+ cell separation from umbilical cord blood. Transfusion 2013;53:2675-2680.

23. Notta F, Doulatov $S$, Dick JE. Engraftment of human hematopoietic stem cells is more efficient in female NOD/SCID/IL-2Rgc-null recipients. Blood 2010;115:3704-3707.

24. Sumikuma $T$, Shimazaki $C$, Inaba $T$, Ochiai $N$, Okano $A$, Hatsuse $M$, Ashihara $\mathrm{E}$, Nakagawa M. CD34+/CD90+ cells infused best predict late haematopoietic reconstitution following autologous peripheral blood stem cell transplantation. Br J Haematol 2002;117:238-244.

25. Raynaud CM, Butler JM, Halabi NM, Ahmad FS, Ahmed B, Rafii S, Rafii A. Endothelial cells provide a niche for placental hematopoietic stem/ progenitor cell expansion through broad transcriptomic modification. Stem Cell Res 2013;11:1074-1090. 